\title{
Cellulose-based materials as scaffolds for tissue engineering
}

\author{
Katarina Novotna $\cdot$ Pavel Havelka $\cdot$ Tomas Sopuch $\cdot$ \\ Katerina Kolarova • Vladimira Vosmanska • Vera Lisa • \\ Vaclav Svorcik $\cdot$ Lucie Bacakova
}

Received: 5 April 2013/Accepted: 19 July 2013/Published online: 28 July 2013

(C) The Author(s) 2013. This article is published with open access at Springerlink.com

\begin{abstract}
Two types of cellulose-based materials, 6-carboxycellulose with 2.1 or $6.6 \mathrm{wt} \%$ of $-\mathrm{COOH}$ groups, were prepared and tested for potential use in tissue engineering. The materials were functionalized with arginine, i.e. an amino acid with a basic side chain, or with chitosan, in order to balance the relatively acid character of oxidized cellulose molecules, and were seeded with vascular smooth muscle cells (VSMC). The cell adhesion and growth were then evaluated directly on the materials, and also on the underlying polystyrene culture dishes. Of these two types of studied materials, 6-carboxycellulose with 2.1 $\mathrm{wt} \%$ of $-\mathrm{COOH}$ groups was more appropriate for cell colonization. The cells on this material achieved an elongated shape, while they were spherical in shape on the other materials. The number of cells and the concentration (per $\mathrm{mg}$ of protein) of contractile proteins alpha-actin and SM1 and SM2 myosins, i.e.
\end{abstract}

K. Novotna $\cdot$ V. Lisa $\cdot$ L. Bacakova $(\varangle)$

Department of Biomaterials and Tissue Engineering, Institute of Physiology, Academy of Sciences of the Czech Republic, Videnska 1083, 14220 Prague 4-Krc,

Czech Republic

e-mail: lucy@biomed.cas.cz

P. Havelka

VUOS a.s., Rybitvi 296, 53354 Rybitvi, Czech Republic

Present Address:

P. Havelka

Lonza Biotec s.r.o., Okruzni 134, 28161 Kourim,

Czech Republic markers of the phenotypic maturation of VSMC, were also significantly higher on this material. Functionalization of the material with arginine and chitosan further improved the phenotypic maturation of VSMC. Chitosan also improved the adhesion and growth of these cells. In comparison with the control polystyrene dishes, the proliferation of cells on our cellulose-based materials was relatively low. This suggests that these materials can be used in applications where high proliferation activity of cells is not desirable, e.g. proliferation of VSMC on vascular prostheses. Alternatively, the cell proliferation might be enhanced by another more efficient modification, which would require further research.

Keywords Polysaccharide materials .

Oxidized cellulose $\cdot$ Vascular smooth muscle cells $\cdot$ Cell differentiation $\cdot$ Contractile phenotype $\cdot$ Chitosan

T. Sopuch

SBU Nitroceluloza, Synthesia a.s., Semtin 103,

53002 Pardubice-Semtin, Czech Republic

Present Address:

T. Sopuch

Holzbecher s.r.o., 55203 Ceska Skalice - Zlic,

Czech Republic

K. Kolarova · V. Vosmanska · V. Svorcik Department of Solid State Engineering, Institute of Chemical Technology, 16628 Prague, Czech Republic 


\section{Introduction}

Cellulose is a polysaccharide consisting of a linear chain of several hundred to over ten thousand $\beta(1 \rightarrow 4)$ linked D-glucose units. It was discovered and isolated from green plants by Payen (1838); for a review, see O'Sullivan 1997). It is the most abundant biopolymer on Earth, synthesized by grasses, woody plants, many forms of algae, fungi and some species of bacteria, namely Acetobacter xylinum. Bacterial cellulose is identical to plant cellulose in chemical structure, but it can be produced without contaminant molecules, such as lignin and hemicelluloses, and does not require intensive purification processes. In addition, it is remarkable for its mechanical strength and biocompatibility, so it has often been applied in tissue engineering (Petersen and Gatenholm 2011). For example, tubes $4 \mathrm{~mm}$ in diameter made of bacterial cellulose showed compliance similar to that of human saphenous vein and higher than expanded polytetrafluorethylene (ePTFE) and polyethylene terephthalate (PET), i.e. synthetic polymers currently used for fabricating vascular replacements. At the same time, they supported the development of a layer of vascular smooth muscle cells. These tubes were therefore considered to be suitable for engineering small-caliber vascular grafts (Zahedmanesh et al. 2011).

However, plant cellulose also holds promise for tissue engineering and for other biomedical applications (Kolarova et al. 2013). Various types and modifications of this cellulose are under extensive scientific research, and their biocompatibility and bioactivity have been tested with various cell types (Mikulikova et al. 2008). Regenerated cellulose (i.e., purified cellulose in which short fibers coming from trees are chemically converted into the long fine fibers used in textiles and non-wovens) has been used for constructing three-dimensional tissue with capillaries (Ko and Iwata 2001) and, together with cellulose acetate, also for cardiac tissue engineering (Entcheva et al. 2004). Non-woven cellulose fabrics (Müller et al. 2006) and injectable cellulose-based hydrogels (Vinatier et al. 2009) have been successfully tested as carriers for chondrocytes for cartilage regeneration in vitro and in vivo. Viscose cellulose sponges have been investigated for their biocompatibility with the bone tissue (Märtson et al. 1998), and also as scaffolds for cartilage tissue engineering (Pulkkinen et al. 2006).

Ideal scaffolds used in advanced tissue engineering should be constructed from resorbable materials that degrade in the organism and are gradually replaced by natural extracellular matrix (Collins and Birkinshaw 2013). However, cellulose in the human organism behaves as a non-degradable or very slowly degradable material. For example, the degradation time of viscose cellulose sponges implanted subcutaneously into rats was longer than 60 weeks (Märtson et al. 1999). This very slow degradability of cellulose is due to the absence of enzymes that attack the $\beta(1 \rightarrow 4)$ linkage (these enzymes are present in microbial and fungal cells; for a review, see Märtson et al. 1999). An efficient method for inducing degradability of cellulose is its oxidation. Oxidized cellulose can be generated by various techniques and by various oxidizing agents, such as $\mathrm{NaClO}_{2}, \mathrm{CCl}_{4}$, nitrogene oxides or free nitroxyl radicals (TEMPO oxidation; Kumar and Yang 2002; Zimnitsky et al. 2004; Saito et al. 2007). Oxidized cellulose is degradable by hydrolysis, by mediated hydrolytic enzymes present in the serum supplement of cell culture media in vitro, and in vivo, in macrophages (Dimitrijevich et al. 1990a, b).

Cellulose oxidation induces conversion of the glucose residues to glucuronic acid residues containing $-\mathrm{COOH}$ groups. The concentration of these groups modulates not only the degradation time of cellulose, but also its $\mathrm{pH}$, its swelling in a water environment, mechanical stability, drug loading efficiency and other behavior of the material (Zhu et al. 2001). In addition, the-COOH groups, which are polar and negatively charged, can be used for functionalizing the oxidized cellulose with various biomolecules (Zimnitsky et al. 2005, 2006).

Oxidized cellulose has been widely used for many years as a wound healing material with excellent properties, such as high absorbability, antibacterial and antiviral properties, and non-toxic and antiadhesive effects (Mueller et al. 2000; Jeschke et al. 2005; Bassetto et al. 2008; Vytrasova et al. 2008). Due to its ability to initiate or accelerate blood coagulation at the site where it is applied, oxidized cellulose has been used as a hemostatic material (Masova et al. 2003; Schonauer et al. 2004). Oxidized cellulose is also promising as a carrier for controlled drug delivery (Zhu et al. 2001). Oxidized dialdehyde cellulose has been applied as a biodegradable scaffold for tissue engineering (Roychowdhury and Kumar 2006), e.g. of vocal fold lamina propria (Roychowdhury et al. 2009).

In this study, we investigate the adhesion, growth and phenotypic maturation of vascular smooth muscle cells (VSMC) on two types of cellulose materials for 
potential use in soft tissue engineering: oxidized 6-carboxycellulose with $2.1 \mathrm{wt} \%$ of $-\mathrm{COOH}$ groups (2.1) and oxidized 6-carboxycellulose with $6.6 \mathrm{wt} \%$ of - $\mathrm{COOH}$ groups (6.6). In order to compensate the relatively acid character of oxidized cellulose molecules (Nagamatsu et al. 1997), the materials were functionalized with arginine, i.e. an amino acid with a basic side chain (Harms et al. 2011), or with chitosan, a linear cationic polysaccharide which has been shown to improve the adhesion and growth of several types of cells, e.g. vascular endothelial cells (Rubenstein et al. 2010), skin keratinocytes (Kingkaew et al. 2010) and 3 T3 fibroblasts (Weltrowski et al. 2012) on cellulosebased scaffolds.

\section{Experimental}

Oxidation of cellulose scaffolds

Pure multifilament viscose silk yarn was used for knitting the starting cellulose tissue. Special attention was paid to avoiding use of any lubricants during knitting in order to protect the cellulose tissue material against hydrophobic substances that would be difficult to remove. The tissues were developed on demand for purposes of this study. Cellulose tissues were oxidized in an organic solvent. Perfluorosol PFS-1 was used as the organic solvent, and nitrogen tetroxide was used as the oxidizing agent. The mixture of a solution of nitrogen tetroxide (10 vol\%) in PFS-1 (90 vol\%) was prepared. To obtain a desirable degree of oxidation (1-22\%), the process was performed at room temperature for designated times. After the oxidation, the washing process in demineralized water was performed, as follows: in demineralized water, in a water solution of isopropyl alcohol in a concentration of $50 \mathrm{wt} \%$, and in $100 \%$ isopropyl alcohol. Drying was carried out in the open air, at room temperature. Biofunctionalized cellulose scaffolds were prepared from oxidized cellulose containing 2.1 or $6.6 \mathrm{wt} \%$ of $-\mathrm{COOH}$ groups. The content of - $\mathrm{COOH}$ groups was determined by the standard acidobasic titrimetric method for oxidized cellulose according to the United States Pharmacopoeia.

Biofunctionalization of cellulose scaffolds

Cellulose-based materials (listed above) in the form of woven fibrous scaffolds were exposed to solutions of arginine or chitosan (USA, Sigma-Aldrich) for $2 \mathrm{~h}$ at room temperature $\left(20{ }^{\circ} \mathrm{C}\right)$. The quantities of particular substances used for preparing the solutions are summarized in Table 1 . The samples were then washed 2 times for $2 \mathrm{~h}$ in isopropyl alcohol and air-dried.

Characterization of the materials

Scanning electron microscopy (SEM)

Scanning electron microscopy (SEM) with the VEGA 3 LMU, TESCAN (CZ) device with voltage $20 \mathrm{eV}$ was used for studying the surface morphology. The samples were covered with gold (the thickness of a layer was ca $15 \mathrm{~nm}$ ) in a sputter coater with glow discharge.

\section{$X$-ray photoelectron spectroscopy (XPS)}

XPS spectra were obtained on the Omicron Nanotechnology ESCAProbeP spectrometer. The dimensions of the exposed and analyzed area were $2 \times 3 \mathrm{~mm}^{2}$. The measuring conditions were as follows, monochromated X-ray source at $1486.7 \mathrm{eV}$ with measuring step $0.05 \mathrm{eV}$ and take-off angle 0 with respect to the surface normal, penetration depth $1 \mathrm{~nm}$. Measurements were made in an ultralight vacuum. The evaluation of the acquired spectra was carried out by CasaXPS code (Svorcik et al. 2009).

\section{Fourier transform infrared spectroscopy (FTIR)}

The changes in chemical structure were examined by FTIR on a Bruker NICOLET 6700 ISF 66/V spectrometer (Thermo, Nicolet, USA) with a GladiATR

Table 1 Quantity of ingredients of the arginine (arg) or chitosan (chit) solution that was used for functionalization of primal materials $(2.1,6.6$ : 6-carboxycellulose with 2.1 and $6.6 \mathrm{wt} \%$ of $-\mathrm{COOH}$ groups, respectively)

\begin{tabular}{lllll}
\hline $\begin{array}{l}\text { Prepared } \\
\text { biofunctionalized } \\
\text { material }\end{array}$ & $\begin{array}{l}\text { Primal } \\
\text { textile } \\
\text { material } \\
(\mathrm{g})\end{array}$ & $\begin{array}{l}\text { Arginine } \\
\text { or } \\
\text { chitosan } \\
(\mathrm{g})\end{array}$ & $\begin{array}{l}\text { Acetic } \\
\text { acid } \\
(\mathrm{ml})\end{array}$ & $\begin{array}{l}\text { Distilled } \\
\mathrm{H}_{2} \mathrm{O}(\mathrm{ml})\end{array}$ \\
\hline $\begin{array}{l}2.1+\arg \\
2.1+\mathrm{chit}\end{array}$ & 6 & $1.48(\arg )$ & 0 & 150 \\
$6.6+\arg$ & 6 & $6(\mathrm{chit})$ & 2.5 & 500 \\
$6.6+$ chit & 6 & $4.76(\arg )$ & 0 & 150 \\
\hline
\end{tabular}


diamond ATR extension. The differential FTIR spectra presented in this study were determined by subtracting the FTIR spectra of non-functionalized samples from those of functionalized samples.

\section{pH measurements}

The samples were cut out on circles $1 \mathrm{~cm}$ in diameter. The samples were immersed into distilled water at laboratory temperature, volume $50 \mathrm{ml}$. The $\mathrm{pH}$ values were written down every $30 \mathrm{~s}$ for a period of $40 \mathrm{~min}$. The solutions were remeasured after $48 \mathrm{~h}$. The $\mathrm{pH}$ was examined using an Orion Star A211 pH meter.

Cells and culture conditions

\section{Evaluation of cell adhesion and growth}

Samples of cellulose fabrics $2 \times 2 \mathrm{~cm}$ in size were sterilized by UV light for $1 \mathrm{~h}$ on each side. Sterilization by UV light appeared to be the most appropriate approach for this kind of material, as sterilization in ethanol or in an autoclave in our preliminary experiments caused morphological, chemical and mechanical instability of the samples. After sterilization, the samples were inserted into 12-well culture plates (well diameter $2.2 \mathrm{~cm}$; TPP, Switzerland). To prevent the samples floating in the culture medium, they were fixed to the well bottoms with plastic rings, and then seeded with vascular smooth muscle cells, derived from rat aorta by an explantation method (Bacakova et al. 1997). The cells (passage 4) were seeded at a initial density of 60,000 cells/well (i.e., about 16,000 cells $/ \mathrm{cm}^{2}$ ). The cells were cultured in Dulbecco's modified Eagle's Minimum Essential Medium (DMEM; Sigma, U.S.A., Cat. No. D5648) supplemented with $10 \%$ fetal bovine serum (FBS; Sebak $\mathrm{GmbH}$, Aidenbach, Germany) and gentamicin (40 $\mu \mathrm{g} / \mathrm{ml}$, LEK, Ljubljana, Slovenia) at $37^{\circ} \mathrm{C}$ in a humidified atmosphere containing $5 \%$ of $\mathrm{CO}_{2}$ in the air. Materials with $6.6 \mathrm{wt} \%$ of $-\mathrm{COOH}$ groups, especially those non-modified with arginine and chitosan, caused an excessive decrease in the $\mathrm{pH}$ of the culture medium, indicated by the phenol red $\mathrm{pH}$ indicator contained in the medium, which changed the colour of the medium from pink to yellow as early as a few hours after seeding. The medium was therefore replaced by a fresh medium, and after it had been replaced the same effect did not recur.
On the 2nd, 4th and 7th day after seeding, the cells were rinsed with phosphate-buffered saline (PBS; Sigma-Aldrich), detached from the materials by a trypsin-EDTA solution (Sigma, USA, Cat. No. T4174) and counted using a Bürker haemocytometer. Two independent samples were used for each time interval and experimental group.

\section{Evaluation of the cell viability and morphology}

The cells on the materials and also on the underlying polystyrene dishes were stained with the viability/ cytotoxicity (LIVE/DEAD) kit for mammalian cells (Invitrogen, Molecular Probes, USA) on days 2, 4 and 7 according to the manufacturer's protocol. After being rinsed with PBS, the cells were incubated (10 min, $20{ }^{\circ} \mathrm{C}$ ) in a mixture of calcein AM, which detects the esterase activity in living cells and produces a green fluorescence, and ethidium homodimer-1, which labels the dead cells by penetrating into them through their damaged membrane and generating a red fluorescence. Microphotographs of the cells were taken using a conventional fluorescence microscope (Olympus IX 50, Japan) complemented by a digital camera (DP 70, Japan).

Immunofluorescence staining of alpha-actin and SM1 and SM2 myosins

The cellulose-based scaffolds were cut into square pieces $(1 \times 1 \mathrm{~cm})$ and sterilized by UV light. All materials were washed in PBS and in the culture medium (mentioned above) in order to increase the $\mathrm{pH}$ of the oxidized samples (particularly materials with $6.6 \mathrm{wt} \%$ of $-\mathrm{COOH}$ groups), and were fixed to the well bottoms with plastic rings. Twenty-four-well culture plates (well diameter $1.5 \mathrm{~cm}$; TPP, Switzerland) were used for cell cultivation, and vascular smooth muscle cells (passage 8) were seeded at a density of 30,000 cells/well (i.e., about 17,000 cells/ $\mathrm{cm}^{2}$ ). The cells were cultured in DMEM, as mentioned above ( $1 \mathrm{ml} /$ well; Sigma, USA, Cat. No. D5648) supplemented with $10 \%$ FBS (Sebak GmbH, Aidenbach, Germany) and gentamicin $(40 \mu \mathrm{g} / \mathrm{ml}$, LEK, Ljubljana, Slovenia) at $37{ }^{\circ} \mathrm{C}$ in a humidified atmosphere containing $5 \%$ of $\mathrm{CO}_{2}$ in the air.

The contractile proteins alpha-actin and SM1 and SM2 myosins, important markers of the phenotypic maturation of VSMC towards the contractile phenotype, were visualized by immunofluorescence. On the 
7 th day after seeding, the cells were fixed with $70 \%$ methanol $\left(-20{ }^{\circ} \mathrm{C}, 10-20 \mathrm{~min}\right)$. In order to block nonspecific binding sites and to permeabilize the cells, the samples were pretreated with $1 \%$ bovine serum albumin and $0.1 \%$ Triton X-100 (Sigma) in PBS for $20 \mathrm{~min}$ at room temperature. Then the cells were incubated with the following primary antibodies: monoclonal anti-alpha smooth muscle actin (clone 1A4, Cat. No. A2547, Sigma) and monoclonal antimyosin (clone hSM-V, Cat. No. M7786, Sigma), which were diluted in PBS to achieve concentrations of 1:200 (anti-alpha actin) and 1:100 (anti-myosin). The cells were kept at $4{ }^{\circ} \mathrm{C}$ in the antibody solutions overnight. After the cells had been rinsed with PBS, the secondary antibody, i.e. $\mathrm{F}\left(\mathrm{ab}^{\prime}\right) 2$ fragment of goat anti-mouse $\operatorname{IgG}(\mathrm{H}+\mathrm{L})$ conjugated with Alexa Fluor $^{\circledR} 488$ and diluted in PBS to a concentration of 1:400, was added to both samples for $1 \mathrm{~h}\left(20^{\circ} \mathrm{C}\right)$. The cells were then evaluated using a fluorescence microscope (Olympus IX 71, Japan) equipped with a digital camera (DP 71, Japan).

\section{Enzyme-linked immunosorbent assay (ELISA) of alpha-actin and SM1 and SM2 myosins}

The materials were inserted into 6-well culture plates (TPP, Switzerland, diameter $3.4 \mathrm{~cm}$ ) and seeded with VSMC at an initial density of 200,000 cells/well (about 22,000 cells $/ \mathrm{cm}^{2}$ ). On day 7 after seeding, the cells were detached from the materials and also from the underlying polystyrene dishes, using the trypsinEDTA solution mentioned above, and were counted in a Bürker haemocytometer.

The cells were resuspended in distilled and deionized water and homogenized by ultrasonication (UP100H Ultrasonic Processor, Schoeller) for $20 \mathrm{~s}$. The total content of protein was measured using the modified Lowry method (Lowry et al. 1951). Aliquots of the cell homogenates were diluted to the same concentrations $(50 \mu \mathrm{g}$ of total protein $/ \mathrm{ml})$. The aliquots were further used in 3 different concentrations $(1,5,10 \mu \mathrm{g} / \mathrm{ml})$, and were adsorbed on 96-well microtiter plates $(50 \mu \mathrm{l}$ of water with protein/well, Maxisorp, NUNC) overnight at $4{ }^{\circ} \mathrm{C}$. After being washed twice with PBS, the non-specific binding sites were blocked by $0.02 \%$ gelatine in PBS (100 $\mu \mathrm{l} /$ well, $1 \mathrm{~h})$. Then the following steps were applied: (1) $1 \%$ Tween $^{\circledR} 20$ (Sigma) for $20 \mathrm{~min}(100 \mu \mathrm{l} /$ well), (2) washing in PBS, (3) washing twice in PBS with $0.1 \%$
Triton X-100, (4) washing in PBS. After that, the primary antibodies (the same as used for immunofluorescence staining), i.e. monoclonal anti-alpha actin and monoclonal anti-myosin (both diluted in PBS to concentration 1:200) were applied for $1 \mathrm{~h}(50 \mu \mathrm{l} /$ well). Subsequent washing in PBS with $0.05 \%$ Tween (3 times) was followed by applying the secondary antibody goat anti-mouse IgG conjugated with peroxidase (Cat. No. A3682, Sigma) for $45 \mathrm{~min}$. After washing in PBS with $0.05 \%$ Tween (3 times) again, a chromogen was applied $(100 \mu \mathrm{l} /$ well $)$, and the plates were left for 10-30 min in the dark. The chromogen was prepared by mixing the following chemicals: (1) $10 \mathrm{ml}$ of $0.1 \mathrm{M} \mathrm{Na}_{2} \mathrm{HPO}_{4} \cdot 12 \mathrm{H}_{2} \mathrm{O}$, (2) $5 \mathrm{mg}$ of orthophenylenediamine dihydrochloride, and (3) $17 \mu \mathrm{l}$ of $30 \% \mathrm{H}_{2} \mathrm{O}_{2}$. To stop the chromogen-protein reaction, $2 \mathrm{M} \mathrm{H}_{2} \mathrm{SO}_{4}$ was used (50 $\mu \mathrm{l} /$ well). The absorbances were measured using a Versa Max ELISA Reader at $490 \mathrm{~nm}$ wavelength, and were expressed as a percentage of the control value obtained from cells growing on PS dishes with no cellulose material.

\section{Statistical analysis}

The quantitative data was presented as mean \pm S.E.M. (Standard Error of Mean) from 36 measurements. Multiple comparison procedures were performed by the One Way Analysis of Variance (ANOVA), Student-Newman-Keuls method, using SigmaStat software (Jandel Corp. USA). $P$ values equal to or $<0.05$ were considered significant.

\section{Results and discussion}

\section{Surface morphology}

SEM images of the cellulose-based samples are shown in Fig. 1. The fibers of 6-carboxycellulose are relatively smooth, knitted into a thick fabric with a typical multi-lobe cross-section due to the production process. A single fiber has an average width of $20 \mu \mathrm{m}$. Figure $1 b, d$ and $f$ show detailed images of single lobes. The average width of one lobe does not exceed $5 \mu \mathrm{m}$. There are no significant differences among the samples of 6-carboxycellulose with 2.1 or $6.6 \mathrm{wt} \%$ of $-\mathrm{COOH}$ groups. The images of the functionalized samples look similar to the previous images. 

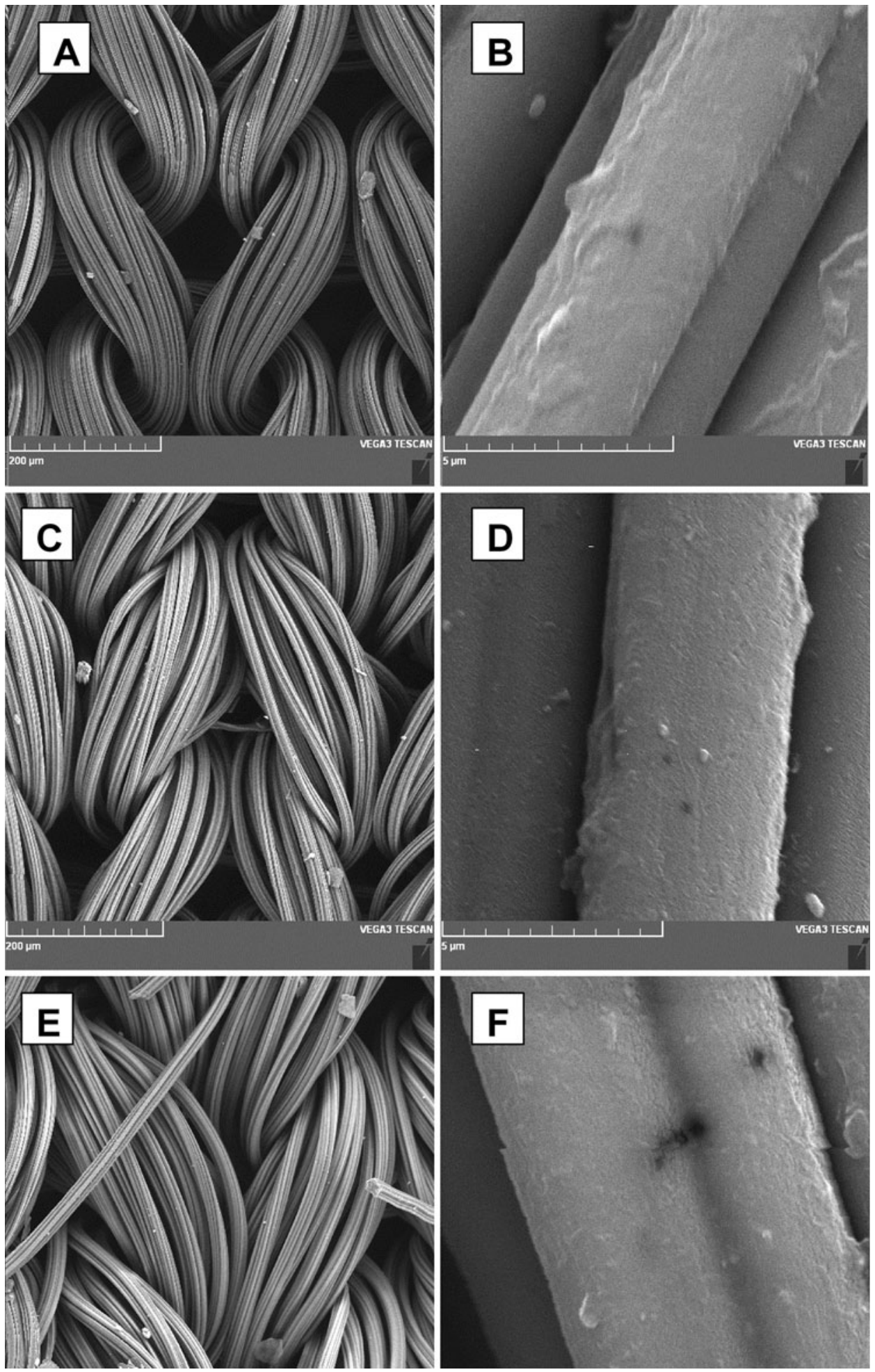

Fig. 1 SEM images of non-oxidized 6-carboxycellulose (a, b), 6-carboxycellulose with $2.1 \mathrm{wt} \%(\mathbf{c}, \mathbf{d})$ and $6.6 \mathrm{wt} \%(\mathbf{e}, \mathbf{f})$ of $-\mathrm{COOH}$ groups. Bar $=200 \mu \mathrm{m}(\mathbf{a}, \mathbf{c}, \mathbf{e})$ and $5 \mu \mathrm{m}(\mathbf{b}, \mathbf{d}, \mathbf{f})$ 
Chemical analysis

Figure 2 shows the XPS spectra of chitosan-functionalized samples of 6-carboxycellulose with 2.1 or $6.6 \mathrm{wt} \%$ of $-\mathrm{COOH}$ groups. The nitrogen content in the case of chitosan corresponds to the line at $398.5 \mathrm{eV}$. This line can be seen clearly in both spectra. The nitrogen content was detected in the amount of 5.1 at\% for 2.16 -carboxycellulose functionalized with chitosan and 5.6 at\% for 6.66 -carboxycelullose functionalized with chitosan.

Both arginine- and chitosan-functionalized samples were further analyzed by FTIR spectroscopy. Fig. 3 shows that both samples contain peaks typical for arginine (2 912, $2843 v$ valence vibrations of $\mathrm{CH}$ in $-\mathrm{CH}_{2}$ symmetric and asymmetric, 1594 vibration of amidic group -CO-NH- and $1400 \mathrm{~cm}^{-1}-\Delta-\mathrm{CH}_{2}$ deformation vibration for samples functionalized by arginine) (Petrosyan and Sukiasyan 2008) and for chitosan (2 912, $2843 v$ valence vibrations of $\mathrm{CH}$ in $-\mathrm{CH}_{2}$ symmetric and asymmetric, 1598 vibration of amidic group -CO-NH-, 1539 product of oxidation, $1061-$ glycosidic bond and $987 \mathrm{~cm}^{-1}$ hydroxyl

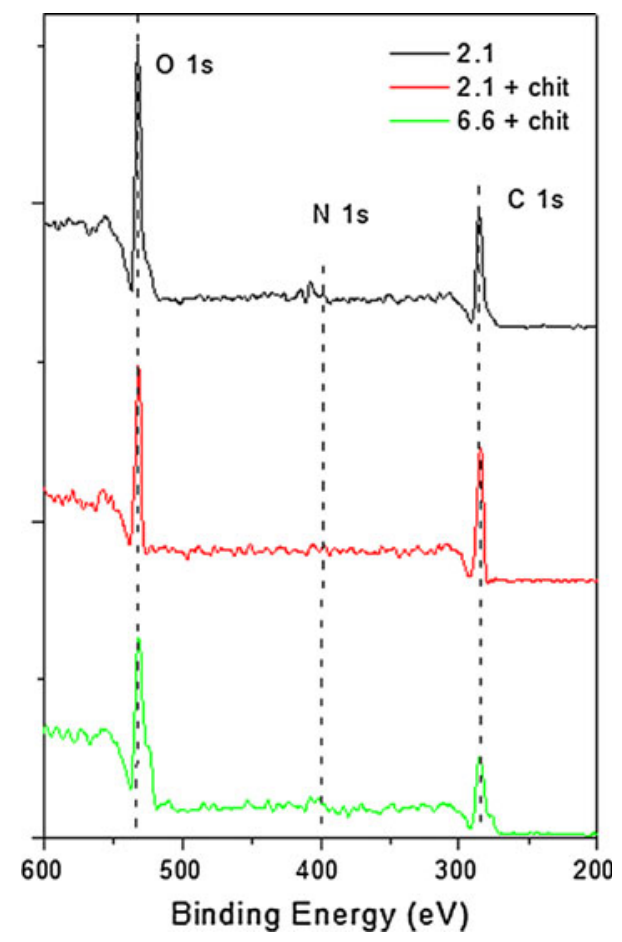

Fig. 2 XPS spectra of 6-carboxycellulose with $2.1 \mathrm{wt} \%$ of $-\mathrm{COOH}$ groups (non-functionalized and functionalized with chitosan) and $6.6 \mathrm{wt} \%$ of $-\mathrm{COOH}$ groups (functionalized with chitosan) group for samples functionalized by chitosan) (Lawrie et al. 2007).

\section{$\mathrm{pH}$ Measurements}

For the purposes of biological experiments, it is useful to know the behavior of the samples in aqueous solutions. When carboxycellulose is suspended in water, no appreciable solvation takes place, even after several weeks at $37{ }^{\circ} \mathrm{C}$, but a fall in $\mathrm{pH}$ is observed. In

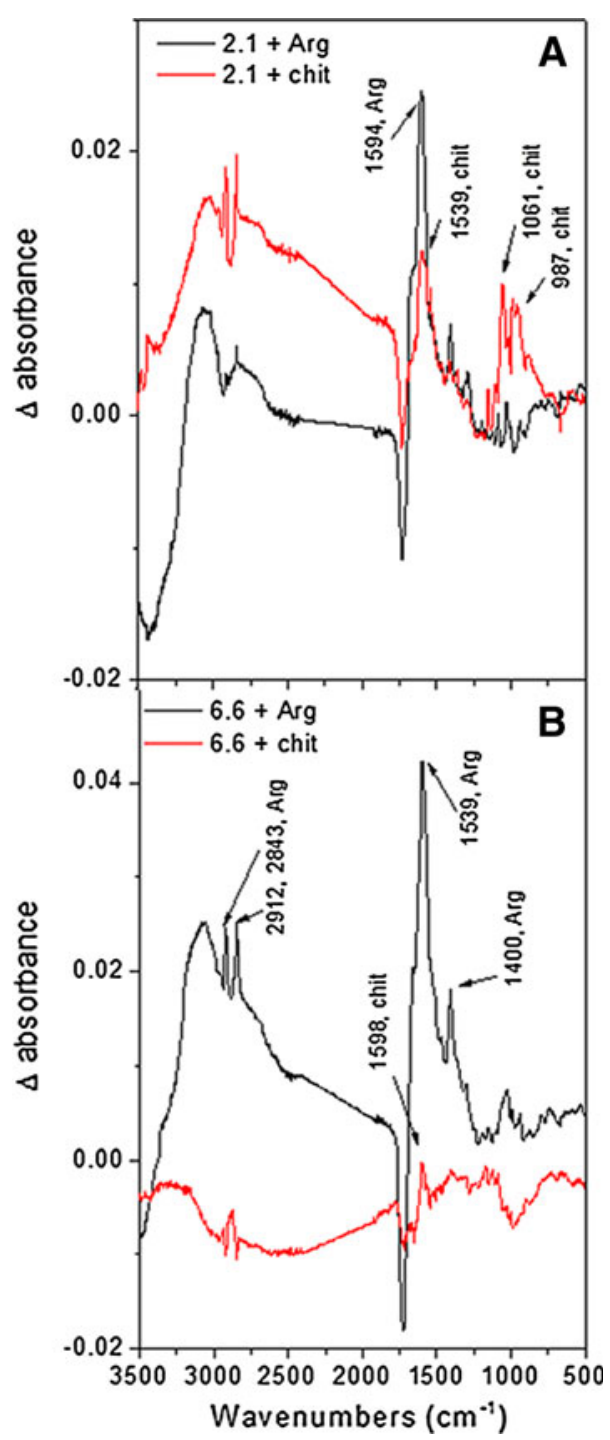

Fig. 3 FTIR spectra of 6-carboxycellulose with 2.1 (a) and 6.6 wt $\%$ of $-\mathrm{COOH}$ groups (b) functionalized with chitosan or arginine. The resultant spectra were obtained by subtracting a control scan (i.e., without arginine or chitosan) and a scan of the material modified with arginine or chitosan 
Fig. 4, the dependence of the $\mathrm{pH}$ values on the immersion time in distilled water can be observed. Samples of 6-carboxycellulose with $6.6 \mathrm{wt} \%$ of $-\mathrm{COOH}$ groups show a more significant decrease in the $\mathrm{pH}$ values than 6-carboxycellulose with $2.1 \mathrm{wt} \%$ of $-\mathrm{COOH}$ groups, owing to the higher amount of carboxyl groups. The $\mathrm{pH}$ values of solutions with oxidized 6-carboxycellulose show a rapid decrease in the $\mathrm{pH}$ values during the first $15 \mathrm{~min}$. After $45 \mathrm{~min}$, the $\mathrm{pH}$ values are stable and the slightly acid environment ( $\mathrm{pH}$ value under 5) prevents both materials dissolving. This is in accordance with the following statement that oxidized 6-carboxycellulose shows a polyanionic character immediately after coming in touch with a weak base. Continual titration is therefore needed to retain a stable $\mathrm{pH}$ value. A similar phenomenon can be observed in the biological system (in vivo) because of the natural buffering ability of the organism. Oxidized cellulose implanted in the body of a laboratory animal undergoes immediate degradation up to oligomers, which are then hydrolyzed to smaller fragments and finally to D-glucuronic acid, D-glucose (Dimitrijevich et al.

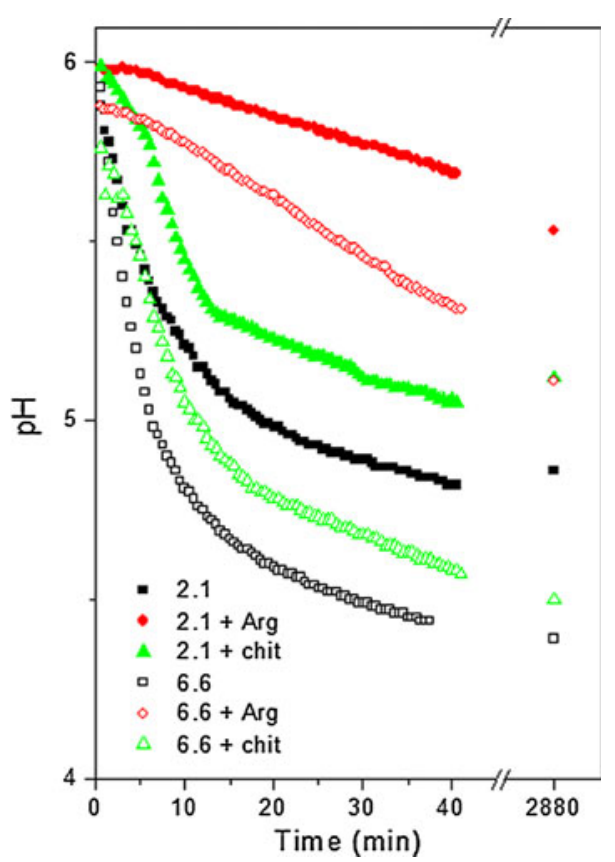

Fig. 4 Dependence of the $\mathrm{pH}$ values on time of immersion in distilled water of 6-carboxycellulose with $2.1 \mathrm{wt} \%$ of $-\mathrm{COOH}$ groups (non-functionalized and functionalized with arginine and chitosan) and $6.6 \mathrm{wt} \%$ of $-\mathrm{COOH}$ groups (non-functionalized and functionalized with arginine or chitosan) 1990a, b). Higher $\mathrm{pH}$ values in arginine and chitosanfunctionalized samples can be caused by the presence of amino groups in the samples. Arginine (Arg) is an ionizable amino acid. It is generally known that the antibacterial activity of chitosan is enhanced by lowering the $\mathrm{pH}$ values (Tsai and $\mathrm{Su}$ 1999). Accordingly, it can be presumed that the naturally acidic character of oxidized 6-carboxycellulose will support the antibacterial effectiveness of chitosan bound on the surface of the oxidized 6-carboxycellulose.

Adhesion and growth of VSMC on cellulose-based materials

In this study, we investigated the biocompatibility of 6-carboxycellulose with 2.1 or $6 \mathrm{wt} \%$ of $-\mathrm{COOH}$ groups for its potential use as a scaffold in tissue engineering. The materials were tested as non-modified and as modified with arginine and chitosan. Positively charged amine groups in these biomolecules were expected to support the adsorption of cell adhesion-mediating molecules and cell adhesion. At the same time, amino acids with the basic side chain (such as lysin, arginine), as well as chitosan, were assumed to balance the relatively acid character of oxidized cellulose molecules (Nagamatsu et al. 1997). Although this balancing effect was more apparent in samples functionalized with arginine than in samples functionalized with chitosan, the adhesion and subsequent growth were improved more apparently on the materials functionalized with chitosan.

On day 2 after seeding, the number of VSMC adhered to 6-carboxycellulose with $2.1 \mathrm{wt} \%$ of $-\mathrm{COOH}$ groups and $6.6 \mathrm{wt} \%$ of $-\mathrm{COOH}$ groups was relatively low (2 $850 \pm 390$ cells $/ \mathrm{cm}^{2}$ and 2 $920 \pm 400$ cells $/ \mathrm{cm}^{2}$, respectively). For comparison, the initial seeding density was 16000 cells $/ \mathrm{cm}^{2}$, and on the bottoms of the control polystyrene wells without materials, the cell population density was 8 $820 \pm 760$ cells $/ \mathrm{cm}^{2}$. After functionalization with arginine, the cell population density on both types of 6-carboxycellulose remained similar to the population density on the non-modified materials. However, after functionalization with chitosan, the cell population density increased to $4380 \pm 460$ and $4380 \pm$ 520 cells $/ \mathrm{cm}^{2}$ on 6-carboxycellulose with 2.1 and $6.6 \mathrm{wt} \%$ of $-\mathrm{COOH}$ groups, respectively.

On day 4 after seeding, the cell numbers on all cellulose-based samples became slightly higher, 
Number of cells cultivated for 7 days on 6-carboxycellulose and on PS

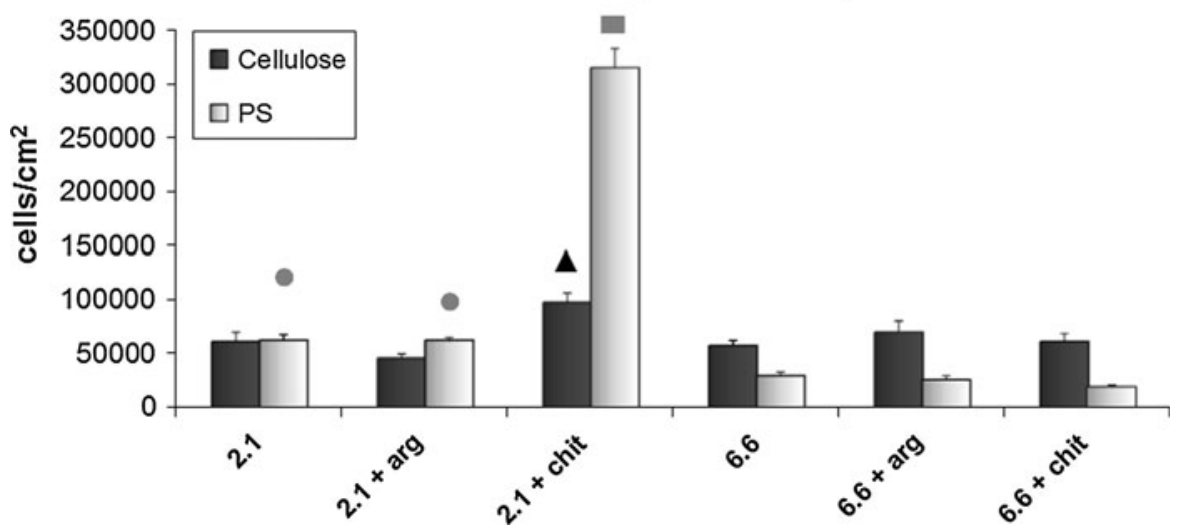

Fig. 5 Number of VSMC on day 7 after seeding on 6-carboxycellulose with 2.1 or $6.6 \mathrm{wt} \%$ of $-\mathrm{COOH}$ groups (2.1 and 6.6 , respectively), and on the bottoms of polystyrene culture dishes $(P S)$ in the presence of these materials. The materials were functionalized with chitosan (chit) or arginine ( $\mathrm{arg}$ ). Mean \pm S.E.M. from 18 measurements from 6 independent samples for each experimental group. ANOVA, Student-

ranging from $4510 \pm 530$ to $7010 \pm 750 \mathrm{cells} / \mathrm{cm}^{2}$, while on the control polystyrene wells, the cell population density reached $61390 \pm 3060 \mathrm{cells} / \mathrm{cm}^{2}$. The influence of functionalization with arginine and chitosan on the cell number was similar as on day 1 .

On day 7 , the increase in cell numbers on the cellulose-based materials was more apparent. The cell population densities on these materials ranged from $46200 \pm 4590$ to $97830 \pm 8840$ cells $/ \mathrm{cm}^{2}$. The highest numbers were achieved on 6-carboxycellulose with $2.1 \mathrm{wt} \%$ of $-\mathrm{COOH}$ groups modified with chitosan. A relatively low cell number was found on 6-carboxycellulose with $6.6 \mathrm{wt} \%$ of $-\mathrm{COOH}$ groups, and functionalization with Arg and chitosan did not improve the cell growth on these materials (Fig. 5). The cell numbers on the bottoms of the polystyrene dishes containing the tested materials ranged from $19470 \pm 2200$ to $316120 \pm 17650 \mathrm{cells} / \mathrm{cm}^{2}$, and had a similar trend as on the corresponding material samples. The lowest cell numbers were found in the dishes containing 6-carboxycellulose with $6.6 \mathrm{wt} \%$ of $-\mathrm{COOH}$ groups, and the highest numbers were found in the dishes containing 6-carboxycellulose with $2.1 \mathrm{wt} \%$ of $-\mathrm{COOH}$ groups modified with chitosan (Fig. 5).

Positive effects of chitosan on the adhesion and growth of cells were also reported for vascular endothelial cells grown on cellulose acetate-chitosan
Newman-Keuls method applied for multiple comparisons. Statistical significance $(p \leq 0.05)$ : filled square value in $2.1+$ chit (PS) is significantly higher than in all other samples (PS), filled circle values in 2.1 and 2.1+arg (PS) are significantly higher than in all other samples (PS), except 2.1+chit (PS), filled triangle value in $2.1+$ chit (Cellulose) is significantly higher than in all other samples

composites (Rubenstein et al. 2010), skin keratinocytes on bacterial cellulose-chitosan films (Kingkaew et al. 2010) or for 3 T3 fibroblasts on cellulose sulfates and chitosan sulfates (Weltrowski et al. 2012). Chitosan has also been shown to have positive influence on cell differentiation, e.g. on the osteogenic differentiation of $\mathrm{C} 2 \mathrm{C} 12$ myoblasts in combination with the bone morphogenetic protein-2 (Peschel et al. 2012). In accordance with this, functionalization of 6-carboxycellulose with $2.1 \mathrm{wt} \%$ of $-\mathrm{COOH}$ groups with chitosan in our study significantly increased the concentration of alpha actin and SM1 and SM2 myosins, i.e. markers of VSMC differentiation toward the contractile phenotype, in cells on these samples (see below). The positive effects of chitosan on the cell performance on cellulose-based materials have been explained by several factors, e.g. improvement of the mechanical properties of the cellulose materials by chitosan (Rubenstein et al. 2010), protection of growth factors against their proteolytic cleavage by chitosan (Weltrowski et al. 2012), and interaction of positively charged amino groups of chitosan and negatively charged cell membranes (Kingkaew et al. 2010). In this context, derivatives of microdispersed oxidized cellulose and arginine, which also contains positively charged amino groups, stimulated the proliferation of human peripheral blood leukocytes and mouse splenocytes (Jelinkova et al. 2002). Positively charged 

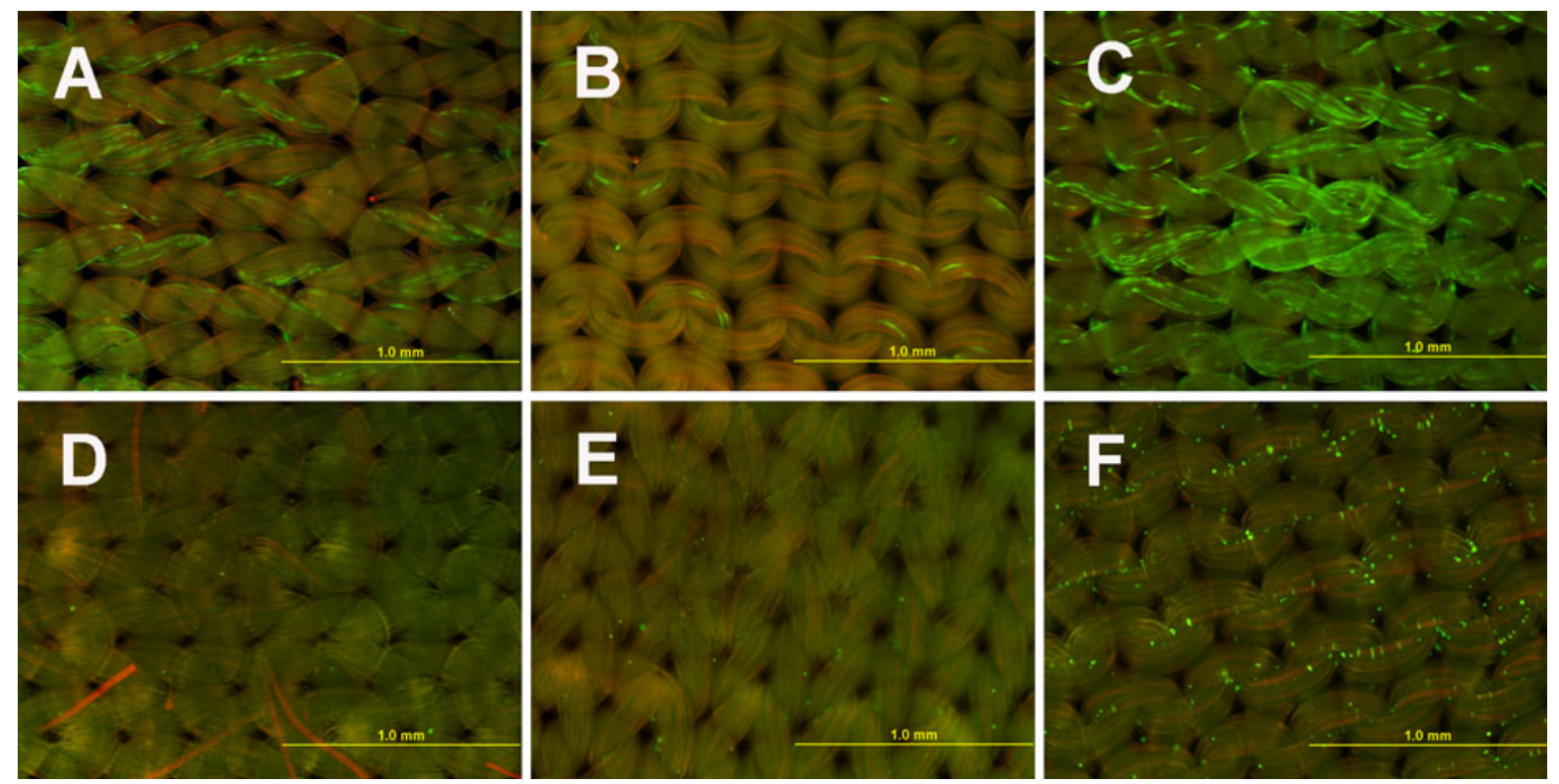

Fig. 6 Morphology and viability of vascular smooth muscle cells on day 7 after seeding on oxidized cellulose with $2.1 \mathrm{wt} \%$ of $-\mathrm{COOH}$ groups $(\mathbf{a}, \mathbf{b}, \mathbf{c})$ and on oxidized cellulose with $6.6 \mathrm{wt} \%$ of $-\mathrm{COOH}$ groups $(\mathbf{d}, \mathbf{e}, \mathbf{f})$; materials with no modification (a, d), materials functionalized with arginine (b, e), materials functionalized with chitosan (c, f). LIVE/DEAD staining, obj. $4 \times$. Olympus IX 51 microscope, DP 70 digital camera, obj. $4 \times$, bar $=1 \mathrm{~mm}$
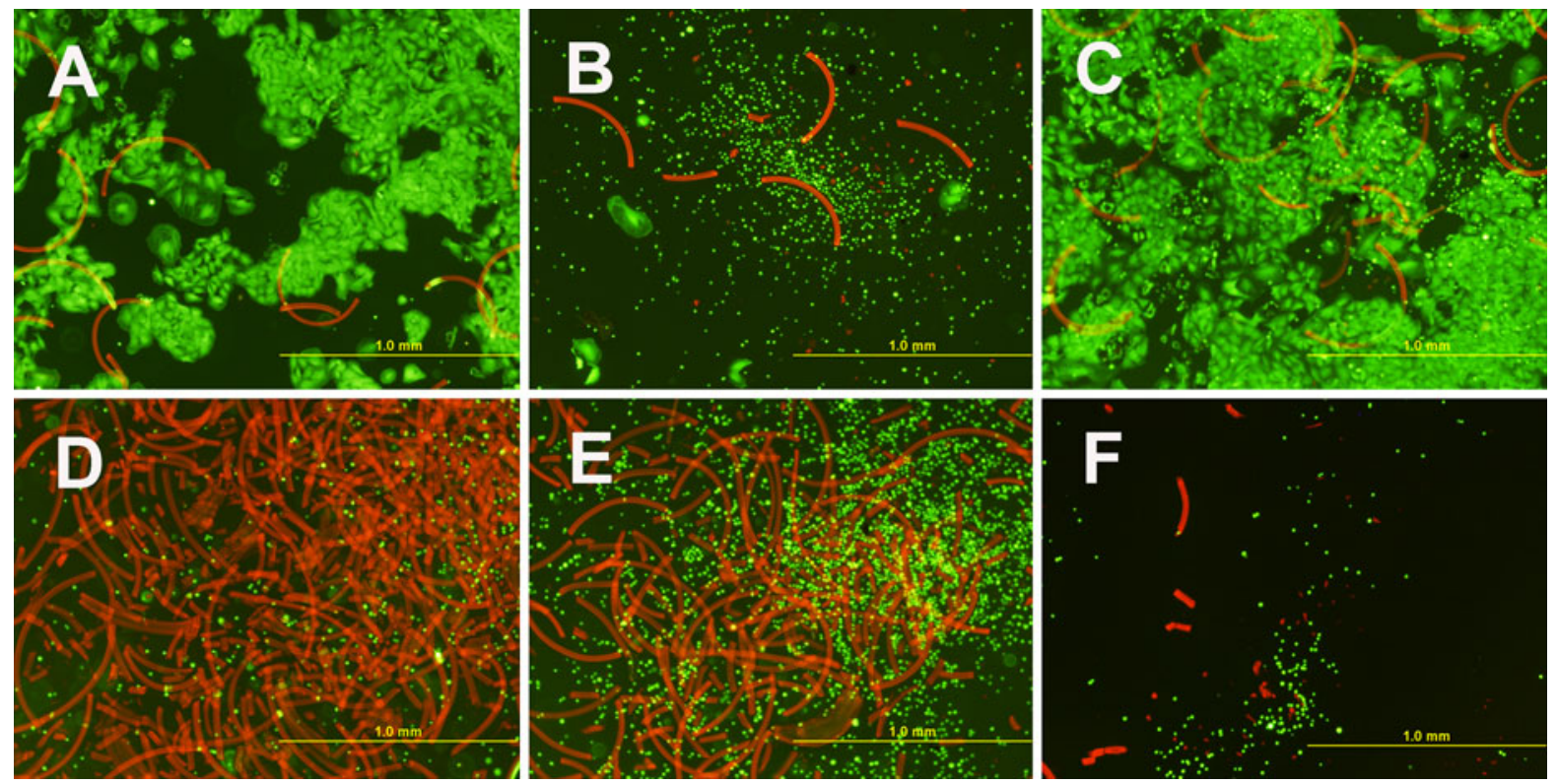

Fig. 7 Morphology and viability of vascular smooth muscle cells on day 7 after seeding on the bottoms of polystyrene dishes containing oxidized cellulose with $2.1 \mathrm{wt} \%$ of $-\mathrm{COOH}$ groups $(\mathbf{a}, \mathbf{b}, \mathbf{c})$ and on oxidized cellulose with $6.6 \mathrm{wt} \%$ of $-\mathrm{COOH}$

materials are also believed to improve the adsorption of cell adhesion-mediating extracellular matrix (ECM) proteins, such as fibronectin, vitronectin, groups (d, e, f); materials with no modification (a, d), materials functionalized with arginine $(\mathbf{b}, \mathbf{e})$, materials functionalized with chitosan $(\mathbf{c}, \mathbf{f})$. LIVE/DEAD staining, obj. $4 \times$. Olympus IX 51 microscope, DP 70 digital camera, obj. $4 \times$, bar $=1 \mathrm{~mm}$

collagen and laminin from biological fluids to materials in an advantageous geometrical conformation, which promotes binding between cell adhesion 
receptors and their ligands in the ECM molecules (for a review, see Bacakova et al. 2011). Interestingly, the positive effects of chitosan functionalization were seen not only in cells growing directly on the tested materials, but also in cells on the underlying PS dishes. In the case of 6-carboxycellulose with $2.1 \mathrm{wt} \%$ of $-\mathrm{COOH}$, the increase in cell number was even more apparent on the underlying PS dishes than directly on the materials. Conversely, in the case of materials less appropriate for cell adhesion and growth, such as 6-carboxycellulose with $6.6 \mathrm{wt} \%$ of $-\mathrm{COOH}$, the cell number was also low on the underlying PS dishes (Fig. 5). This suggests that our materials may release factors influencing cell behavior into the cell culture medium. In case of 6-carboxycellulose with $6.6 \mathrm{wt} \%$ of $-\mathrm{COOH}$, the high acidity of this material probably also had a negative influence on the adhesion and growth of cells on the materials and on the underlying PS dishes.

Higher oxidation of 6-carboxycellulose caused not only higher acidity of this material, but also lower stability of the material in the cell culture environment. The content of $6.6 \mathrm{wt} \%$ of $-\mathrm{COOH}$ groups appeared to be too high from this point of view, as these samples disintegrated in the culture medium when they were subjected to simple manipulation. The stability of 6-carboxycellulose with $2.1 \mathrm{wt} \%$ of - $\mathrm{COOH}$ was sufficiently high, as it did not disintegrate when the samples were manipulated, and its degradation in the cell culture system was relatively slow in comparison with the samples with $6.6 \mathrm{wt} \%$ of $-\mathrm{COOH}$

Morphology and viability of VSMC on cellulosebased materials

There was also an observable contrast in the cell morphology and vialbility of the materials. On the 6-carboxycellulose samples with $2.1 \mathrm{wt} \%$ of $-\mathrm{COOH}$ groups (unmodified or modified with arginine, and particularly with chitosan), the cells were relatively well-spread, as indicated by their spindle-like shape, elongated in the direction of the material fibers (Fig. 6). By contrast, the cells on the 6-carboxycellulose with $6.6 \mathrm{wt} \%$ of $-\mathrm{COOH}$ groups were spherical, which indicates weak adhesion and spreading of these cells. Nevertheless, staining with the LIVE/DEAD viability/cytotoxicity kit revealed high viability of the cells. Most cells were stained with green fluorescence, which indicates esterase activity in these cells. Only a few cells were stained in red, and were thus dead, even on the materials less appropriate for cell adhesion. Interestingly, some material fibers were non-specifically stained in red, or emitted a red autofluorescence (e.g., Fig. 6d).

A similar picture was found in cells grown on polystyrene dishes in the presence of cellulose-based materials. The cells in the presence of 6-carboxycellulose with $2.1 \mathrm{wt} \%$ of $-\mathrm{COOH}$ groups (unmodified, and modified with chitosan) were mostly well-spread, polygonal and morphologically similar to the cells on the control polystyrene dishes without materials. In the presence of the other materials, the cells were round and non-spread, although they are mostly viable. The fibrous structures (stained in red) which remained on the bottom of the polystyrene dishes after the material samples were removed, indicate degradation of the materials, particularly 6-carboxycellulose with $6.6 \mathrm{wt} \%$ of $-\mathrm{COOH}$ in unmodified state (Fig. 7d).

Phenotypic maturation of VSMC on cellulosebased materials

In a mature healthy blood vessel, the vascular smooth muscle cells are in so-called contractile phenotype. This phenotype is characterized by the presence of contractile proteins $\alpha$-actin and SM1 and SM2 isoforms of myosin, muscle type of tropomyosin, T-troponin, h-caldesmon, h1-calponin, meta-vinculin, desmin - a protein of intermediate filaments, and other specific markers. The migratory and proliferative activity of contractile VSMC is very low or none, and the amount of organelles involved in proteosynthesis, such as endoplasmic reticulum, ribosomes or Golgi complex, is also low. However, the synthetic phenotype of VSMC is manifested by high migration and proliferation activity of VSMC, loss of $\alpha$-actin and SM1 and SM2 myosins, predominance of $\beta$ - and $\gamma$ isoforms of actin and non-muscle myosin, and an increased amount of synthetic organelles. This phenotype occurs physiologically in immature blood vessels under development, pathologically in diseased blood vessels, e.g. during atherosclerosis, hypertension and inflammation, and artificially after disintegration of the vascular wall and seeding VSMC in vitro (for a review, see Orr et al. 2009; Beamish et al. 2010; Parizek et al. 2011). 

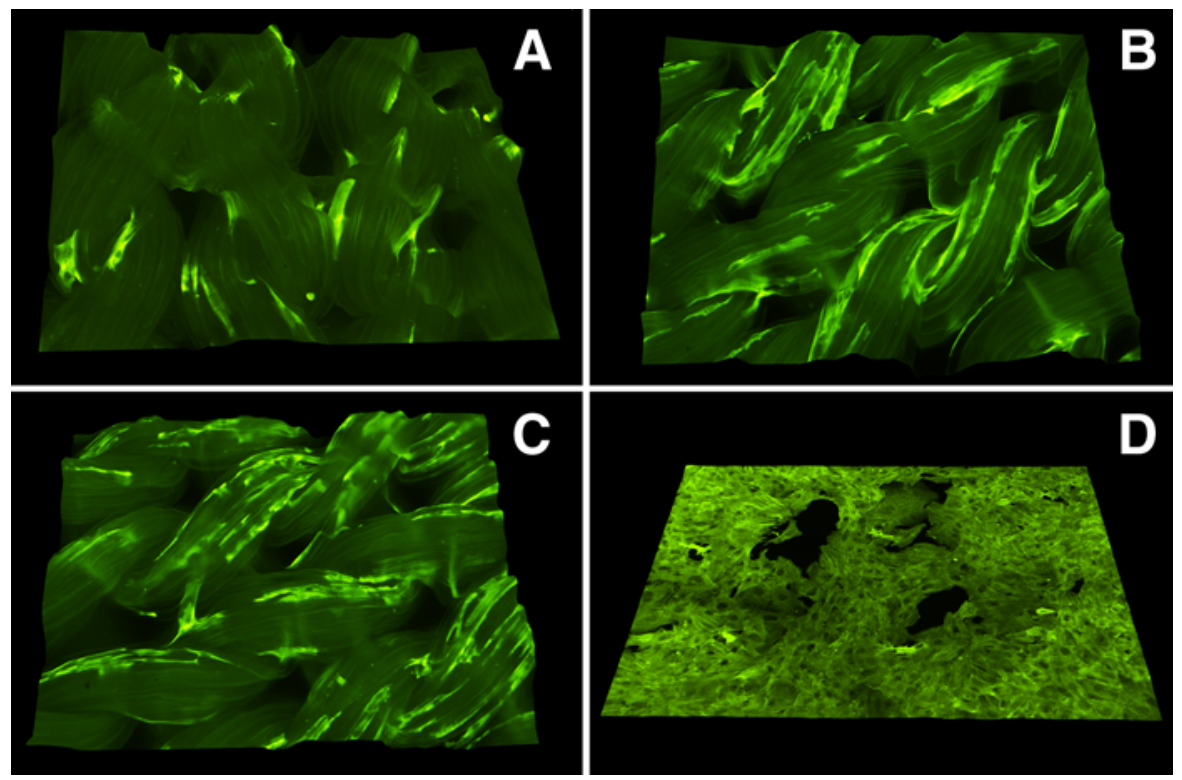

Fig. 8 3D reconstruction of the surfaces of 6-carboxycellulose with $2.1 \mathrm{wt} \%$ of $-\mathrm{COOH}$ groups without functionalization (a), functionalized with arginine (b) or chitosan (c), and of a control microscopic glass coverslip (d), colonized with rat aortic smooth muscle cells (day 7 after seeding). The cells were

However, the contractile phenotype of VSMC in vitro can be restored, at least partially, by the culture conditions, e.g. by appropriate dynamic cultivation, composition of cell culture media and also by the physical and chemical properties of the growth substrate. The maturation of VSMC towards the contractile phenotype was most pronounced on materials based on 6-carboxycellulose with $2.1 \mathrm{wt} \%$ of -COOH groups. Immunofluorescence showed that the cells on these materials, and also on the underlying polystyrene dishes, were brightly stained for $\alpha$-actin and SM1 and SM2 myosins, particularly the cells on 6-carboxycellulose with $2.1 \mathrm{wt} \%$ of $-\mathrm{COOH}$ groups modified with chitosan. However, the actin and myosin fibers in these cells were less distinguishable, because the cells on these materials were markedly elongated along the cellulose fibers, and thus very thin (Figs. 8, 9). On the control flat surfaces, namely polystyrene dishes and microscopic glass coverslips, the cells were polygonal and were filled with $\alpha$-actinor myosin-containing filaments, distinguishable at higher magnifications (data not shown here).

ELISA confirmed that after functionalization of 6-carboxycellulose with $2.1 \mathrm{wt} \%$ of $-\mathrm{COOH}$ groups immunostained against alpha-actin. Nikon Eclipse Ti-E microscope, obj. $10 \times 1.5$; Nikon DS-Qi1 MC digital camera, NISElements AR software, version 3.10. Summarization of Z-sections with deconvolution

with chitosan or arginine, the concentration of $\alpha$-actin in the cells on these samples increased significantly in comparison with all other materials, including the control polystyrene dishes. The concentrations of SM1 and SM2 myosins in cells on 6-carboxycellulose with $2.1 \mathrm{wt} \%$ of $-\mathrm{COOH}$ groups with chitosan or arginine or in its unmodified state also became significantly higher than in cells on 6-carboxycellulose with $6.6 \mathrm{wt} \%$ of $-\mathrm{COOH}$ groups and the control polystyrene (Fig. 10).

The tested materials based on 6-carboxycellulose with $2.1 \mathrm{wt} \%$ of $-\mathrm{COOH}$ groups allowed considerable adhesion and spreading of VSMC (while on the 6-carboxycellulose with $2.1 \mathrm{wt} \%$ of $-\mathrm{COOH}$ groups samples, the cells remained rather round). However, the fibers in the knitted cellulose fabric, aligned in parallel, guided the shape of the adhering VSMC to be elongated, i.e. reminiscent of the physiological spindle-like shape of contractile and quiescent VSMC in the tunica media of mature healthy blood vessels (Villaschi et al. 1994). In some in vitro studies, elongated and spindle-like shape of the VSMC was also associated with lower proliferation activity and a higher differentiation status of these cells (Chen et al. 2011). Another factor supporting the phenotypic 

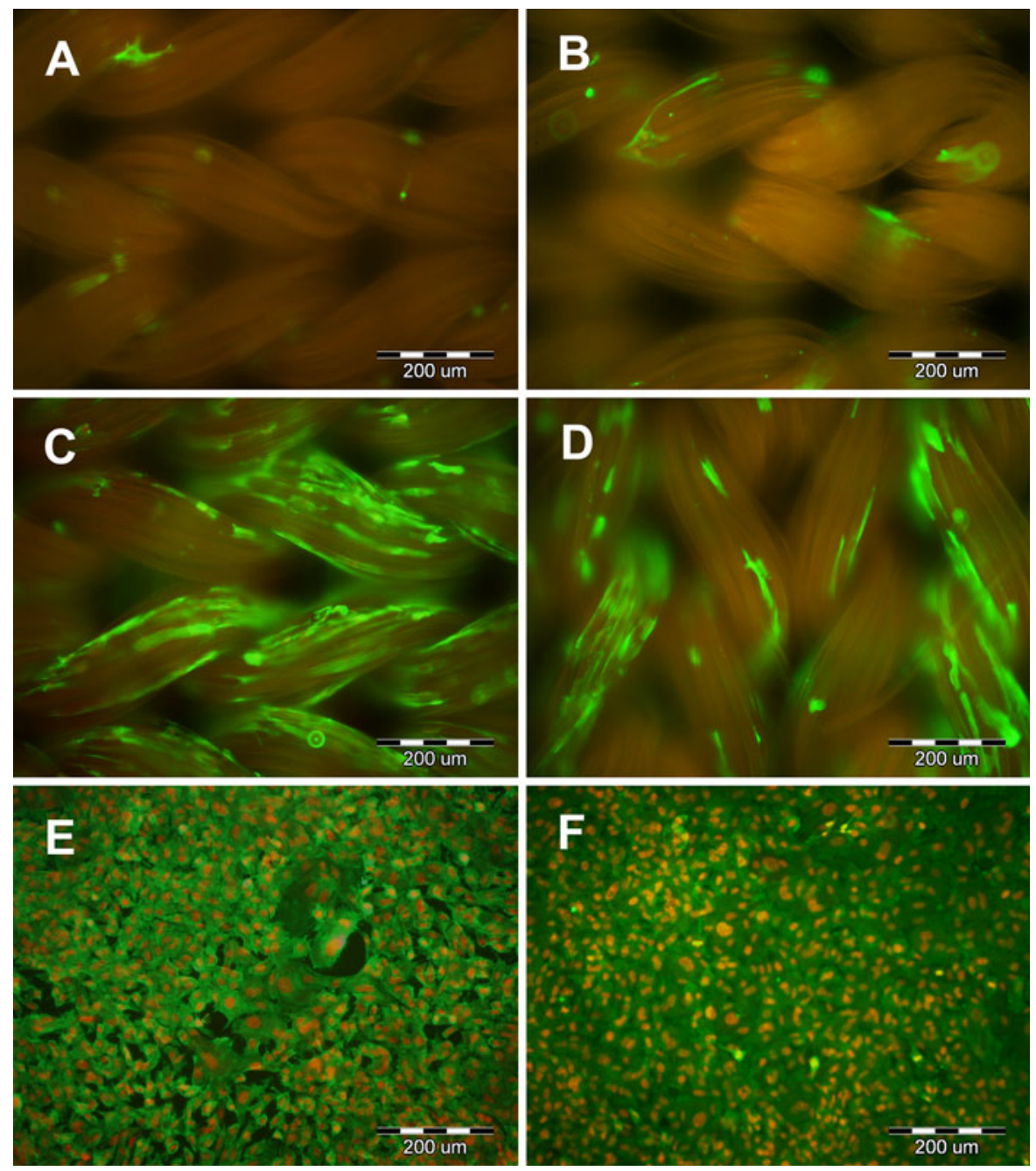

Fig. 9 Immunofluorescence staining of alpha-actin $(\mathbf{a}, \mathbf{c}, \mathbf{e})$ and SM1 and SM2 myosins (b, d, f) in cells growing on 6-carboxycellulose with $2.1 \mathrm{wt} \%$ of $-\mathrm{COOH}$ groups $(\mathbf{a}, \mathbf{b})$, 6-carboxycellulose with $2.1 \mathrm{wt} \%$ of $-\mathrm{COOH}$ groups modified

with chitosan (c, d) and on control polystyrene dishes (e, f). Day 7 after seeding, Olympus IX 71 microscope, DP 70 digital camera, obj. $20 \times$, bar $=200 \mu \mathrm{m}$

maturation of cells could be the acidity of the oxidized cellulose materials, which in the case of 6-carboxycellulose with a low concentration $(2.1 \mathrm{wt} \%)$ of - $\mathrm{COOH}$ groups was relatively mild, and did not kill the cells but only restricted their proliferation and thus started their differentiation program.

Thus, 6-carboxycellulose with $2.1 \mathrm{wt} \%$ of $-\mathrm{COOH}$ groups would be suitable for tissue engineering applications where differentiation and phenotypic maturation of cells is required rather than their high proliferation rate. An example of an application of this kind is the construction of bioartificial vascular replacements, in which an excessive proliferation of VSMC can cause stenosis or obliteration of their lumen (Mol et al. 2008; Shinoka and Breuer 2008). Another positive factor is the relatively low degradability and high stability of 6-carboxycellulose with $2.1 \mathrm{wt} \%$ of $-\mathrm{COOH}$ groups. In other degradable polymers considered for the construction of vascular replacements, the degradation time is usually too short for the creation of new tissue, which can lead to the development of an aneurysm (Greisler et al. 1991). For example, polylactides, polyglycolides and their copolymers usually degrade within weeks and months, 

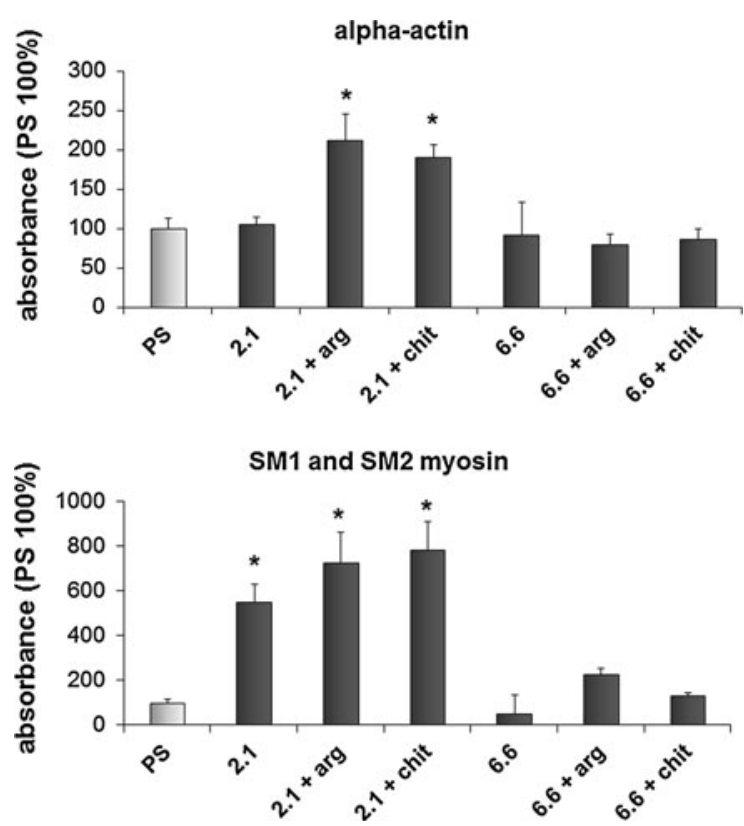

Fig. 10 Concentration of alpha-actin and SM1 and SM2 myosin in VSMC on day 7 after seeding on 6-carboxycellulose materials (see legend to Fig. 5). Measured by ELISA per mg of protein, absorbance values were expressed in \% of values obtained from cells grown on control PS. Mean \pm S.E.M. from 6 measurements from 2 independent samples for each experimental group. ANOVA, Student-Newman-Keuls method. Statistical significance $(p \leq 0.05)$ : alpha-actin: asterisk values in 2.1+chit and 2.1+arg are significantly higher than on all other samples; Myosin: asterisk Values in 2.1, 2.1+chit and 2.1+arg are significantly higher than in all other samples

whereas for human vessel reconstruction, the degradation time should be considered to be more than 1 year, particularly in older and polymorbid patients with very slow tissue regeneration.

In order to further improve the attractiveness of cellulose-based materials for cell colonization, not only modification with chitosan and arginine but also other modifications can be considered. These modifications involve plasma, ion or UV irradiation, which are proved to increase the attractiveness of synthetic polymers for cell adhesion and growth (Parizek et al. 2009; for a review, see Bacakova et al. 2011). Plasma modification increased the adsorption of chitosan to cellulose (Fras Zemljic et al. 2009). Another important modification is functionalization with various biomolecules, such as fibronectin (Ko and Iwata 2001), and particularly ECM-derived adhesion oligopeptides (e.g., RGD), which has also been successfully applied in cellulose-based materials (Bodin et al. 2007).

\section{Conclusion}

The results that we have obtained indicate that oxidized cellulose with $2.1 \mathrm{wt} \%$ of $-\mathrm{COOH}$ groups could be an appropriate material for tissue engineering, due to its relatively high stability during manipulation and exposure to the cell culture environment, and its biocompatibility, which can be further improved by modification with biomolecules, particularly chitosan. As it induces the most appropriate spreading and phenotypic maturation of cells, but not considerable cell proliferation, it could be used in the construction of bioartificial tissues or organs, where high proliferation activity of cells is not desired. A possible application of this material is for constructing bioartificial vascular prostheses, where excessive growth activity of cells on the material may cause stenosis and failure of these replacements.

Acknowledgments This study was supported by Grant No. 2A-1TP1/073 of the Ministry of Industry and Trade of the Czech Republic, and by Grant No. P108/12/1168 of the Grant Agency of the Czech Republic. Mr. Robin Healey (Czech Technical University, Prague) is gratefully acknowledged for his language revision of the manuscript.

Open Access This article is distributed under the terms of the Creative Commons Attribution License which permits any use, distribution, and reproduction in any medium, provided the original author(s) and the source are credited.

\section{References}

Bacakova L, Mares V, Lisa V, Bottone MG, Pellicciari C, Kocourek F (1997) Sex-related differences in the migration and proliferation of rat aortic smooth muscle cells in short and long term culture. In Vitro Cell Dev Biol 33:410-413

Bacakova L, Filova E, Parizek M, Ruml T, Svorcik V (2011) Modulation of cell adhesion, proliferation and differentiation on materials designed for body implants. Biotechnol Adv 29:739-767

Bassetto F, Vindigni V, Scarpa C, Botti C, Botti G (2008) Use of oxidized regenerated cellulose to stop bleeding after a facelift procedure. Aesthetic Plast Surg 32:807-809

Beamish JA, He P, Kottke-Marchant K, Marchant RE (2010) Molecular regulation of contractile smooth muscle cell phenotype: implications for vascular tissue engineering. Tissue Eng Part B Rev 16:467-491

Bodin A, Ahrenstedt L, Fink H, Brumer H, Risberg B, Gatenholm P (2007) Modification of nanocellulose with a xyloglucan-RGD conjugate enhances adhesion and proliferation of endothelial cells: implications for tissue engineering. Biomacromolecules 8:3697-3704 
Chen J, Yin H, Jiang Y, Radhakrishnan SK, Huang ZP, Li J, Shi Z, Kilsdonk EP, Gui Y, Wang DZ, Zheng XL (2011) Induction of microRNA-1 by myocardin in smooth muscle cells inhibits cell proliferation. Arterioscler Thromb Vasc Biol 31:368-375

Collins MN, Birkinshaw C (2013) Hyaluronic acid based scaffolds for tissue engineering-a review. Carbohydr Polym 92:1262-1279

Dimitrijevich SD, Tatarko M, Gracy RW, Linsky CB, Olsen C (1990a) Biodegradation of oxidized regenerated cellulose. Carbohydr Res 195:247-256

Dimitrijevich SD, Tatarko M, Gracy RW, Wise GE, Oakford LX, Linsky CB, Kamp L (1990b) In vivo degradation of oxidized, regenerated cellulose. Carbohydr Res 198: 331-341

Entcheva E, Bien H, Yin L, Chung Ch, Farrell M, Kostov Y (2004) Functional cardiac cell constructs on cellulosebased scaffolding. Biomaterials 25:5753-5762

Fras Zemljic L, Persin Z, Stenius P (2009) Improvement of chitosan adsorption onto cellulosic fabrics by plasma treatment. Biomacromolecules 10:1181-1187

Greisler HP, Tattersall CW, Klosak JJ, Cabusao EA, Garfield JD, Kim DU (1991) Partially bioresorbable vascular grafts in dogs. Surgery 110:645-654, discussion 654-655

Harms MJ, Schlessman JL, Sue GR (2011) Arginine residues at internal positions in a protein are always charged. PNAS 108:18954-18959

Jelinkova M, Briestensky J, Santar I, Rihova B (2002) In vitro and in vivo immunomodulatory effects of microdispersed oxidized cellulose. Int Immunopharmacol 2:1429-1441

Jeschke MG, Sandmann G, Schubert T, Klein D (2005) Effect of oxidized regenerated cellulose/collagen matrix on dermal and epidermal healing and growth factors in an acute wound. Wound Repair Regen 13:324-331

Kingkaew J, Jatupaiboon N, Sanchavanakit N, Pavasant P, Phisalaphong M (2010) Biocompatibility and growth of human keratinocytes and fibroblasts on biosynthesized cellulose-chitosan film. J Biomater Sci Polym Ed 21: 1009-1021

Ko IK, Iwata H (2001) An approach to constructing threedimensional tissue. Ann NYAcad Sci 944:443-455

Kolarova K, Vosmanska V, Rimpelova S, Svorcik V (2013) Effect of plasma treatment on cellulose fiber. Cellulose 20:953-961

Kumar V, Yang D (2002) $\mathrm{HNO}_{3} / \mathrm{H}_{3} \mathrm{PO}_{4}-\mathrm{NANO}_{2}$ mediated oxidation of cellulose-preparation and characterization of bioabsorbable oxidized celluloses in high yields and with different levels of oxidation. Carbohydr Polym 48: 403-412

Lawrie G, Keen I, Drew B, Chandler-Temple A, Rintoul L, Fredericks P, Grondal L (2007) Interactions between alginate and chitosan biopolymers characterized using FTIR and XPS. Biomacromolecules 8:2533-2541

Lowry OH, Rosebrough NJ, Farr AL, Randall RJ (1951) Protein measurement with the Folin phenol reagent. J Biol Chem 193:265-275

Märtson M, Viljanto J, Hurme T, Saukko P (1998) Biocompatibility of cellulose sponge with bone. Eur Surg Res 30:426-432

Märtson M, Viljanto J, Hurme T, Laippala P, Saukko P (1999) Is cellulose sponge degradable or stable as implantation material? An in vivo subcutaneous study in the rat. Biomaterials 20:1989-1995

Masova L, Rysava J, Krizova P, Suttnar J, Salaj P, Dyr JE, Homola J, Dostalek J, Myska K, Pecka M (2003) Hemostyptic effect of oxidized cellulose on blood platelets. $\mathrm{Sb}$ Lek 104:231-236

Mikulikova R, Svorcik V, Nahlik J, Sopuch T, Havelka P (2008) Cytocompatibility of surface ground PE doped with calcium salt of 6-carboxycellulose. Cellulose 15:473-479

Mol A, Rubbens MP, Stekelenburg M, Baaijens FP (2008) Living heart valve and small-diameter artery substitutesan emerging field for intellectual property development. Recent Pat Biotechnol 2:1-9

Mueller PO, Harmon BG, Hay WP, Amoroso LM (2000) Effect of carboxymethylcellulose and a hyaluronate-carboxymethylcellulose membrane on healing of intestinal anastomoses in horses. Am J Vet Res 61:369-374

Müller FA, Müller L, Hofmann I, Greil P, Wenzel MM, Staudenmaier R (2006) Cellulose-based scaffold materials for cartilage tissue engineering. Biomaterials 27:3955-3963

Nagamatsu M, Podratz J, Windebank AJ, Low PA (1997) Acidity is involved in the development of neuropathy caused by oxidized cellulose. J Neurol Sci 146:97-102

Orr AW, Hastings NE, Blackman BR, Wamhoff BR (2009) Complex regulation and function of the inflammatory smooth muscle cell phenotype in atherosclerosis. J Vasc Res 47:168-180

O'Sullivan AC (1997) Cellulose: the structure slowly unravels. Cellulose 4:173-207

Parizek M, Kasalkova N, Bacakova L, Slepicka P, Lisa V, Svorcik V (2009) Improved adhesion, growth and maturation of vascular smooth muscle cells on polyethylene grafted with bioactive molecules and carbon particles. Int J Mol Sci 10:4352-4374

Parizek M, Novotna K, Bacakova L (2011) The role of smooth muscle cells in vessel wall pathophysiology and reconstruction using bioactive synthetic polymers. Physiol Res 60:419-437

Payen A (1838) Mémoire sur la composition du tissu propre des plantes et du ligneux (Memoir on the composition of the tissue of plants and of woody material). Comptes Rendus 7:1052-1056

Peschel D, Zhang K, Fischer S, Groth T (2012) Modulation of osteogenic activity of BMP-2 by cellulose and chitosan derivatives. Acta Biomater 8:183-193

Petersen N, Gatenholm P (2011) Bacterial cellulose-based materials and medical devices: current state and perspectives. Appl Microbiol Biotechnol 91:1277-1286

Petrosyan AM, Sukiasyan RP (2008) Vibrational spectra of Larginine nitrates. J Mol Struct 874:51-56

Pulkkinen H, Tiitu V, Lammentausta E, Laasanen MS, Hämäläinen ER, Kiviranta I, Lammi MJ (2006) Cellulose sponge as a scaffold for cartilage tissue engineering. Biomed Mater Eng 16:S29-S35

Roychowdhury P, Kumar V (2006) Fabrication and evaluation of porous 2,3-dialdehydecellulose membrane as a potential biodegradable tissue-engineering scaffold. J Biomed Mater Res A 76:300-309

Roychowdhury P, Klemuk S, Titze I, Kumar V (2009) Effects of fabrication parameters on viscoelastic shear modulus of 2,3-dialdehydecellulose membranes-potential scaffolds 
for vocal fold lamina propria tissue engineering. J Biomed Mater Res A 88:680-688

Rubenstein DA, Venkitachalam SM, Zamfir D, Wang F, Lu H, Frame MD, Yin W (2010) In vitro biocompatibility of sheath-core cellulose-acetate-based electrospun scaffolds towards endothelial cells and platelets. J Biomater Sci Polym Ed 21:1713-1736

Saito T, Kimura S, Nishiyama Y, Isogai A (2007) Cellulose nanofibers prepared by TEMPO-mediated oxidation of native cellulose. Biomacromolecules 8:2485-2491

Schonauer C, Tessitore E, Barbagallo G, Albanese V, Moraci A (2004) The use of local agents: bone wax, gelatin, collagen, oxidized cellulose. Eur Spine J 13:S89-S96

Shinoka T, Breuer C (2008) Tissue-engineered blood vessels in pediatric cardiac surgery. Yale J Biol Med 81:161-166

Svorcik V, Chaloupka A, Zaruba K, Kral V, Blahova O, Mackova A, Hnatowicz V (2009) Deposition of gold nanoparticles and nano-layers on polyethylene modified by plasma discharge and chemical treatment. Nucl Instrum Meth B 267:2484-2488

Tsai GJ, Su WH (1999) Antibacterial activity of shrimp chitosan against Escherichia coli. J Food Protec 62:239-243

Villaschi S, Nicosia RF, Smith MR (1994) Isolation of a morphologically and functionally distinct smooth muscle cell type from the intimal aspect of the normal rat aorta. Evidence for smooth muscle cell heterogenity. In Vitro Cell Dev Biol Anim 30A:589-595

Vinatier C, Gauthier O, Fatimi A, Merceron C, Masson M, Moreau A, Moreau F, Fellah B, Weiss P, Guicheux J (2009)
An injectable cellulose-based hydrogel for the transfer of autologous nasal chondrocytes in articular cartilage defects. Biotechnol Bioeng 102:1259-1267

Vytrasova J, Tylsova A, Brozkova I, Cervenka L, Pejchalova M, Havelka P (2008) Antimicrobial effect of oxidized cellulose salts. J Ind Microbiol Biotechnol 35:1247-1252

Weltrowski A, da Silva Almeida ML, Peschel D, Zhang K, Fischer S, Groth T (2012) Mitogenic activity of sulfated chitosan and cellulose derivatives is related to protection of FGF-2 from proteolytic cleavage. Macromol Biosci 12: $740-750$

Zahedmanesh H, Mackle JN, Sellborn A, Drotz K, Bodin A, Gatenholm P, Lally C (2011) Bacterial cellulose as a potential vascular graft: mechanical characterization and constitutive model development. J Biomed Mater Res B Appl Biomater 97:105-113

Zhu L, Kumar V, Banker GS (2001) Examination of oxidized cellulose as a macromolecular prodrug carrier: preparation and characterization of an oxidized cellulose-phenylpropanolamine conjugate. Int J Pharm 223:35-47

Zimnitsky DS, Yurkshtovich TL, Bychkovsky PM (2004) Synthesis and characterization of oxidized cellulose. J Polym Sci A Polym Chem 42:4785-4791

Zimnitsky DS, Yurkshtovich TL, Bychkovsky PM (2005) Multilayer adsorption of amino acids on oxidized cellulose. J Colloid Interface Sci 285:502-508

Zimnitsky DS, Yurkshtovich TL, Bychkovsky PM (2006) Adsorption of zwitterionic drugs onto oxidized cellulose. J Colloid Interface Sci 295:33-40 